\title{
The Network of Spanish Science in Exile
}

\author{
Francisco Javier Dosil Mancilla \\ Instituto de Investigaciones Históricas. Universidad Michoacana de San Nicolás de Hidalgo. México. \\ e-mail: fjdosil@yahoo.es \\ ORCID iD: http://orcid.org/0000-0002-2303-2991
}

Submitted: 2 January 2017. Accepted: 25 May 2017

\begin{abstract}
Spanish science in exile operated as a network of networks. Its dynamics help us understand the deep imprint that exiled scientists left in their host countries. The network was characterized by its tendency to maintain links that had existed before the Spanish Civil War and the establishment of alliances with multiple actors, not just humans, that facilitated the legitimization and integration of exiles while allowing them to resume their research. In addition, those alliances produced shifts of goals that often led those exiled scientists to blaze new trails in scientific research and inaugurate new disciplines. Without doubt, this process fostered the vascularization of science in receiving countries.
\end{abstract}

KEYWORDS: Science; Exile; Networks; Alliances; Shifts of goals.

Citation / Cómo citar este artículo: Dosil Mancilla, Francisco Javier (2018) "The Network of Spanish Science in Exile". Culture \& History Digital Journal, 7 (1): e004. https://doi.org/10.3989/chdj.2018.004

RESUMEN: Las redes de la ciencia española en el exilio.- La ciencia española en el exilio operó como una red de redes cuya dinámica ayuda a comprender la profunda huella que dejaron los científicos desterrados en sus países de acogida. Se caracterizó por la tendencia a mantener los vínculos anteriores a la guerra civil española y a establecer alianzas con otros múltiples actores, no sólo humanos, que facilitaron la legitimación y la integración de los exiliados, así como la reanudación de sus investigaciones. Además, las alianzas determinaron deslizamientos de metas que con frecuencia supusieron la apertura de nuevas rutas y disciplinas científicas. En definitiva, se favoreció la vascularización de la ciencia en estos países.

PALABRAS CLAVE: Ciencia; Exilio; Redes; Alianzas; Deslizamientos de metas.

Copyright: () 2018 CSIC. This is an open-access article distributed under the terms of the Creative Commons Attribution 4.0 International (CC BY 4.0) License.

\section{INTRODUCTION}

Spanish science in exile shone with unusual brilliance and intensity. The key to its success can be understood in various ways: the sum of invaluable individual contributions, the mature fruit of a long political and cultural process that culminated with the $2^{\text {nd }}$ Republic in Spain, a collateral result of scientific endeavors in receiving countries, or the product of academic miscegenation fostered by exodus, among other possibilities. All these explanations are valid and can be studied separately, but attempts to integrate them, like parts of a puzzle, produce the impression that something important is lacking; perhaps the con- cept of movement, which is inherent to a social process like exile? This article seeks to advance our understanding of the dynamics of what I call 'peregrine' science by exploring how the articulation of diverse actors came about, and how new meanings emerged.

Science involves multiple interests -both collective and personal- which form not only a tense scenario with ongoing conflicts, but also concessions and alliances. It seems that the latter prevailed in the science of exile, for refugees are hardly in a position to make demands. Generally-speaking, they sought support from their peers and took advantage of existing bonds to obtain sanctuary and work. Over time, many exiled scientists were able to re- 
sume their intellectual labors, though this entailed reforming their professional ties and modifying the focus of their research. Theirs was a torturous road, one often tragic and plagued with renouncements, but only rarely did those exiles find themselves on their own.

These opening lines offer support for analyzing exile in terms of both banishment and "transtierro" (to use José Gaos' neologism). The concept of banishment is associated with rupture, uprooting, and renouncements, but "transtierro" connotes continuity and collaboration; in this case, Republican Spaniards transplanted in fertile lands where they could take root and prolong their academic careers. The banishment or "transtierro", rupture or continuity, in the science (and culture) of Spaniards in exile is not a new topic, but one that has triggered heated debates and stimulated the pens of expatriate intellectuals like Adolfo Sánchez Vázquez, Francisco Ayala and Gaos. We will not commit the imprudence of arguing in favor of one response or another, for each author legitimately defends his posture as a function of his own experience. Instead, the article explores a third path, based on non-ontological reading of exile that contemplates it as a contour map or a network of networks.

\section{THE RETICULAR FABRIC OF SCIENCE IN EXILE}

The diaspora of scientific expatriates across much of the planet precludes placing exile in a single, concrete scenario. In reality, it configured its own territory: a symbolic order that can be represented as a broad network which transcends national borders. The primordial weave of this fabric consisted of the network of Spanish science that existed before the Civil War, a network that exile shook to its foundations while dispersing its nodes, but connections, broadly-speaking, endured, and that network was soon enriched by new nodes and links, forged through interactions with many other actors.

One example is the Catalan school of physiology, which was deeply fractured by exile. Its principle mentor, Augusto Pi-Suñer, settled in Caracas, where he founded and directed the Institute of Experimental Medicine in the Faculty of Medicine. His disciples were welcomed in various countries, including Mexico (Rosendo Carrasco, Alberto Folch Pi, José Puche, César Pi-Suñer, Jaime Pi-Suñer), the United States (Jorge Folch Pi, Josefa Barba, Francisco Durán, Jordi Casals, Vicente Moragues), Colombia (Manuel Usano), Bolivia (Santiago Pi-Suñer), Great Britain (Jaime Raventós), and Venezuela (Buenaventura Benaiges, Juan Bonfill, Cristián Cortés, Antonio Griñó, Jaime Isern) (Martínez Vidal and Sallent del Colombo, 2010: 144-145). While a contour map of this nature crystallizes destinations, it does not reveal destinies or links, so we must probe more deeply. Augusto PiSuñer, the patriarch, rejected an invitation to move to Mexico City, but his contact with the Mexican physiologist, José Joaquín Izquierdo, led to his sons Jaime and César being accepted instead (Izquierdo, 1966: 246). While travelling through New York, Jaime obtained a do- nation from the Rockefeller Foundation (where he had worked as a researcher in 1934) that he used to create the Laboratory for Biological Research (now the Institute for Biomedical Research at Mexico's National Autonomous University, UNAM), where Cajal's school of histology was incorporated after the Civil War (Dosil Mancilla, 2009). Distance did not impede physiologists from visiting each other frequently and carrying on a fluid exchange of scientific work. A. Pi-Suñer often travelled to Mexico to meet with his family and give conferences. His son Jaime later moved, with Antonio Griñó, to the U.S, for reencounters with physiologists from their school. Also, after a decade in Mexico, Rosendo Carrasco moved to Venezuela to work with his mentor, and Antonio Oriol joined his old companion, Alberto Folch Pi, in the Faculty of General Physiology at the Instituto Politécnico $\mathrm{Na}$ cional in Mexico (IPN); after sojourns in France, Spain and Argentina (Guerra, 2003). These cases show how those physiologists (and Republican scientists, in general) managed to remain in close contact despite their exileinduced dispersal.

But another actor in this story merits our attention: Walter Cannon, a physiologist at Harvard University. During the Civil War, Cannon was active in organizing medical care for the Republican forces (as President of the Medical Aid Committee for Spanish Democracy). After Franco's triumph, he supported their efforts to find political asylum in America. A. Pi-Suñer and Izquierdo had trained under him long before the diaspora. Though they never coincided in Cannon's laboratory, the fact that they shared the same mentor had profound implications for the network of exiles, as it sealed an alliance between those two scientists that explains the support that Izquierdo offered to expatriates, and produces a certain consonance in the conception of physiology and how it favored the integration of exiled Spaniards.

This network of physiologists never suffered severe ruptures, but its physiognomy did undergo a transformation. Scientific links forged long before the Civil War (Cannon, Pi-Suñer, Izquierdo), and attenuated by time and distance, were reaffirmed in exile and served as bridges of solidarity to facilitate the integration of many exiles. Parallel networks (Catalan and Mexican physiology) came to be connected, unexpectedly, through alliances of a humanitarian nature that translated into scientific collaborations. Because of exile, diverse superimposed networks (North American, Mexican and Spanish) spread to other nations (Venezuela, Argentina, Colombia, Bolivia, Great Britain). In this complex web, Cannon served as the clasp that closed the Borromean knot and conserved the linkages among its various chains.

\section{SCIENTIFIC EXILE AS A NETWORK OF NETWORKS}

This example reveals a dynamic network of exile whose movement gradually imbued pre-existing nodes and links with new meanings while broadening through interaction with other networks. To continue our study of 
the dynamics of this network, we examine the case of Ramón Álvarez-Buylla de Aldana, from the city of Oviedo, who fled to Russia as an adolescent during the Civil War. There, he trained as a fighter pilot, but also discovered his scientific vocation, later earning his Doctorate in Physiology at the Academy of Medical Sciences under the direction of Pyotr Anokhin, a direct disciple of Pavlov. Soon, he plunged into research in various laboratories in Rostov, Turkmenia, Leningrad and Moscow (Fernández Guardiola, 1997: 102-107). In 1947, aged just 28 , his professional career took a sudden turn and he moved to Mexico, where his mother and sisters were living, to continue his work in electrophysiology. Thanks to the intervention of the communist leader, Dolores Ibárruri, and carrying a letter of recommendation from Anokhin, he was hired as a professor at the IPN, and was soon named Director of the Neurophysiology Laboratory, where his path crossed those of other Spanish physiologists (José Puche, Alberto Folch Pi, Manuel Castañeda Agulló, Germán García, Ramón Pérez-Cirera, etc.) and he collaborated with Mexican counterparts who had studied with Cannon in Harvard (Izquierdo, Efrén del Pozo, Arturo Rosenblueth).

In this case, exile fostered the convergence of scientific schools from four countries (Russia, the U.S., Spain and Mexico) through the trajectory of one scientist. Can we imagine other such unsuspected and promising encounters? This confluence of traditions took root in adopting countries through the academic work and research of the scientists involved. Among those who benefitted from this process of miscegenation were Álvarez-Buylla's disciple, Pablo Rudomín (a Mexican born to parents of Russian origin) and his son, Arturo Álvarez-Buylla Roces, both of whom were awarded the coveted Premio Principe de Asturias; the father in 1987, in recognition of his studies of spinal fluid, the son in 2011, for the discovery of neuronal regeneration in adult brains.

Exile also tended to generate links with new actors and their networks, including colleagues in host nations, scientific collaborators, political middlemen, sympathizers of the Republican cause, and exiles in other disciplines that offered support despite great adversity. These are the factors that led me to develop the concept of a network of networks of exile; a dense tapestry that allowed, for example, the journal Ciencia to gain broad international diffusion and prestige (Dosil Mancilla and Ramos García, 2011). This network of networks can also be conceived as a contour map which is subject to intense tectonic processes that produce faults, depressions and rifts on its surface. The meaning of faults is easily understood: they represent the distance between nodes caused by exodus (i.e., the dismantling of research groups). Depressions, meanwhile, act as funnels that channel the interests of actors with, heretofore, little in common, towards one specific destination (the journal Ciencia, for example, was sponsored by an affluent, conservative group of Spanish emigrants led by Carlos Prieto, President of the Casino Español and owner of the Fundidora de Fierro y Acero de Monterrey). The concept of rifts has been used in other disciplines as conceptual support for complex thought. In the field of probabilistic physics, Prigogine and Stengers (2004: 274) illustrate this with the metaphor of "baker's transformation": while kneading the dough -continually stretching and folding it- a baker causes transformations that continuously alter the distance between any two points. In the network of networks of exile, similarly, one sole rift may bring two actors face-to-face, though initially they were far apart. This occurred with Álvarez-Buylla, as a rift led him to change his vocation and begin to interact with multiple actors (political and researchers) in four schools of science.

\section{THE POLITICAL EMPIRE OF THE MASSES}

Such analyses of networks are incomplete, however, if they omit that infinity of equipment and beings (magnifying glasses, microscopic preparations, plants, animals, etc.) that assist scientists in their everyday activities. In the years before the Civil War, significant efforts were undertaken to socialize this very heterogeneous guild. José Ortega y Gasset perceived this to some extent in his book La rebelion de las masas (The Rebellion of the Masses), when he warned of the "advent of the masses to full social power", and observed that "the political innovations of recent years mean nothing else than the political empire of the masses" (Ortega y Gasset, 1930: 18), though he fell short by referring only to the unprecedented phenomenon of the crowds of people that, in his time, filled cafés, theaters, trains, beaches, etc., when a much greater multitude had burst into society through interpellation with the scientists with whom they had established a fertile alliance.

This massive socialization that expanded the public sphere was the result of a political and cultural venture that began in the late $19^{\text {th }}$ century and culminated with the $2^{\text {nd }}$ Republic, a period commonly referred to as the Silver Age of Spanish culture. To promote this socialization, new research centers were created (including the laboratories at the Residencia de Estudiantes and the Instituto Español de Oceanografía), some older ones recovered lost luster (like the Museo Nacional de Ciencias Naturales and the Jardín Botánico de Madrid), and societies, specialized journals and congresses multiplied. In universities, students defended doctoral theses that extolled the natural wealth of different regions, and ambitious research projects were begun that compiled, for example, census of biological resources, like the flora and fauna of the Iberian Peninsula. Unfortunately, all this was aborted by the Civil War. Biological phenomena virtually unknown up to that time (polychaetes, isopods, briozoans, seaweed, bryophytes, ferns, etc.) began to fill the pages of journals; new species were included in catalogues that gave them symbolic identity cards and, in a certain sense, 'citizenship'. Other agents socialized in this way were the utensils employed in research (microscopes, stains, reagents, dredgers, spectroscopes, etc.), together with journals, books and identification keys. Alliances with such beings and objects widened scientists' faculties and facili- 
tated the flow and conservation of information. It was not eccentricity that led naturalists to photograph themselves with their microscopes and collections; rather, it was a clear recognition of a hybridization that, in effect, allowed them to perform their work.

Spanish scientists did not sever their links with these actors after the dramatic period of diaspora. Some exiles literally travelled with them stowed in their baggage (many, like Enrique Rioja, may have fled with only the clothes on their backs, but they took their heavy microscopes and collections!); others accompanied them symbolically. This appreciation helps us understand the impact that exiled scientists had in their host countries, which was out of all proportion to their numbers -perhaps a dozen naturalists in Mexico, only a few more chemists and physicist-mathematicians- and cannot be explained by the simplistic argument that "they were few, but very good". Undoubtedly, they were, in general, outstanding professionals, but we cannot disregard the fact that they were not alone. It is not hard to see the importance of alliances in this political scenario, for Republican science was a way of "doing" politics by other means, namely, socializing the greatest number of beings and instruments and contributing to the mobilization of the world; that is, to the ongoing incorporation of these new actors into discourse. Indeed, during the diaspora, these agents formed decisive nodes in the dense scientific network of exile, so let us now examine their intervention at three fundamental moments.

The first involves the process of legitimizing exiled scientists. Like the power of a king, this can be measured by the size of their entourage. Spanish naturalists, for example, achieved professional legitimacy in their host nations largely through the plants and animals they succeeded in socializing. This was their best letter of presentation upon arriving in countries where, with few exceptions, they were completely unknown. Though their names may not have meant much, they were accompanied -in beneficial alliance- by constellations of actors that lacked subjectivity but enjoyed autonomy and internationallyrecognized identities. It is hardly surprising, then, that shortly after their arrival in Mexico, Spanish scientists strove to find opportunities to exhibit the collections of plants and animals that made up their particular entourage, especially in publications, which multiplied at a frenetic pace. The oceanographers Fernando de Buen and Enrique Rioja, for example, each published over thirty articles in their first two years of exile, while the naturalist Bibiano Fernández Osorio-Tafall produced twenty. Recently settled on the Atlantic's other shore, they sought to demonstrate their competence as scientists. To this end, their best-accredited witnesses were, precisely, those unwitting allies.

Second, the guilt of animals and plants performed an important role in integrating exiles into scientific communities in host nations. Mexico offers a case in point. When the Republicans arrived, serious efforts were already underway to socialize beings and objects, and people were convinced that their participation would improve an economy and society severely damaged by the recent revolutionary conflict. As a result, the country witnessed the creation of institutions (like the Instituto de Biología and the Instituto Politécnico Nacional, which provided refuge to many exiles) and the founding of many associations (including the Sociedad Mexicana de Historia Natural), whose periodical publications offered catalogues of flora and fauna, and descriptions of new taxa, etc. Post-revolutionary Mexico broadened its social base to include not only long-marginalized sectors, but also a constellation of actors without subjectivity.

The agents mobilized by scientists of both countries also facilitated the integration of exiles, since they provided a common territory that overflowed national identities and fostered encounters and alliances. On the map of exile, this collective's many interventions can be conceived as funnels that produced surface depressions which channeled diverse actors towards shared interests. As an example, let us look at the exiled naturalists who came to Mexico. They soon organized various scientific excursions with Mexican colleagues to explore, together, largely-unknown habitats. In 1940, they even proposed a research project to the La Casa de España designed to gather collections of plants and animals through the collaboration of scientists from both countries (Casado, 1996). Many similar excursions were initiated by Cándido Bolívar, Federico Bonet and Dionisio Peláez, three Spanish professors at the IPN, and financed by Carlos Prieto, the aforementioned patron of the Spanish colony in Mexico. The journal Ciencia published news of those projects in its section Noticias to disseminate their findings, and results appeared in other specialized journals as well. Such expeditions, motivated by a common fascination with plants and animals, catalyzed the integration of those Spanish naturalists into Mexico's scientific networks. They were spaces that generated all manner of alliances while fomenting the formation of research groups that included young students who, with time, followed the paths traced by their exiled teachers.

Expeditions were also a bridge that conserved links between Spanish naturalists and the Sociedad Mexicana de Historia Natural, a privileged sanctuary devoted to the interpellation and socialization of living beings, through its journal and ordinary sessions where new studies were presented. It was in this scenario that academic links were forged and consolidated, and where interests were channeled to enable the condensation of a shared research program that paved the way for the integration of Republican scientists (Dosil Mancilla, 2006).

This brings us to the third moment of exile in which the participation of these beings and objects proved fundamental. After three years of war, unimaginable sufferings, and their arrival -amidst great uncertainty- in a host country, came the opportunity to resume their studies. Reasons to feel relief abounded -though the European powder keg had just exploded, they were in places of safety- but others caused great angst, for everything was new to those recently-arrived exiles: colleagues, institutions, government science policies, social life, land- 
scapes... Also, many had been unable to do research for several years, had lost their bibliographical materials, and had no instruments with which to work. Moreover, they were unfamiliar with local scientific production, but stretching out before them was a resplendent -though totally unknown- natural world. The urgent question was: Where to begin? The answer: of course, by entrusting much of the work to agents without subjectivity. There were at least two key mechanisms that spurred them to resume their research. On the one hand, we find the alliances that soon emerged between the plants and animals from the two continents for, despite their marked divergences, they shared a genealogy that could function as a bridge between them. On the other, those alliances clearly generated a shifting of goals. To elucidate this concept, think of an association (or syntagm) made up of diverse actors, not just humans (e.g., ABCD), where the substitution or addition of just one actor (or a change in her/his location) modifies the meaning of the association (e.g., BAEDC). Here, post-structuralist linguistics would say that the significant never signifies itself, but that to signify itself it must be directed to another significant. The shifting caused by modifying the association presupposes opening new routes and establishing new scientific disciplines. The next section discusses two case studies.

\section{A MARINE BOTANIST IN THE JUNGLES OF CHIAPAS}

Faustino Miranda González, a botanist from Gijon, arrived in Mexico at age 34. His passion from a young age had been seaweed, a subject to which he devoted over a decade of study. As Spain had no specialists in that field, Miranda was largely self-taught, but in 1928 he defended his doctoral thesis on seaweeds of the Cantabrian coast. Three years later, he went to France on a scholarship and worked for four months in the maritime laboratory of Saint-Servan, in French Brittany, and in the Museum of Natural History in Paris. Returning to Spain, he passed the examinations to qualify as a secondary school teacher. Later, he taught Natural History in Lugo and Pontevedra, and, after 1935, in his hometown, where he set up a modest laboratory equipped with everything he needed to conduct research. His contributions to phycology in Spain were impressive: an exhaustive catalogue of marine flora in the north, identifications of new species, and pioneering studies of the morphology and reproduction of seaweed that are still valid today (Dosil Mancilla, 2007).

Now, imagine this botanist, fascinated by the sea and seaweed, in Mexico's capital city, far from the coast? Miranda had asked himself the same question on board the ship that took him to his adopted country:

Seated on the deck under the brilliant sun of the trade winds, I observed the short 'flight' of the flying fish that soon submerged again into the blue waters of the Atlantic leaving only ripples. Abundant sargassums had begun to appear, passive toys of sea's currents, but I was still far from the coast of America whence seaweed came. Little time had passed, though it seemed like an eternity since the war of ' 36 in Spain had ended [...]. Everything seemed peaceful in the world seen from the middle of the Atlantic. What would I do upon my arrival in Mexico? My [area of] specialization in botanical research was the study of seaweed. But probably, in Mexico, I would have to start all over again; the first thing would be securing food, and after that... well... we'd just have to see. Thinking it was best not to dwell on that, I returned to my contemplation of the immensity of the sea's surface (Miranda, 1963: 23).

Miranda was reluctant to speak of himself, but he wrote this autobiographical note shortly before his death, a quarter of a century after that scene had taken place. But it seems that his text interpellates seaweed as an ally that reached out its arms from both ocean shores to forge a bridge between the Old and New Worlds, though he was aware of the difficulties he would face in resuming his work. And he was not wrong. For two years, he survived by giving classes in private high schools, but then, in 1941, he joined the faculty of the Biology Institute at the UNAM, where he built a career that made him the father of modern Mexican botany. In 1943-1944, he published his final contribution to Spanish phycology: a three-part study that appeared in Ciencia, entitled "Enumeración de las algas marinas del N. y NO. de España". It is highly likely that he had conserved that information all those years, and decided to publish it only when he finally recognized the irreversibility of his exile (Dosil Mancilla and Cremades, 1999). This was his farewell gesture from phycology but, as we shall see below, seaweed never ceased to be present.

This exiled scientist's contributions to botany in Mexico can be synthetized in two broad fields: floristic studies in Chiapas, and the classificatory system he proposed for all the types of vegetation found in the country. Chiapas was a decisive region in Miranda's life: he resided in its capital city for five years (1949-1953), established an Institute and Botanical Garden, and continued exploring its jungles until his final days. He published numerous articles on its flora and a -now classic- book, La vegetación de Chiapas (1953). Contrary to what one might think, tropical and marine ecosystems have many similarities, not in terms of species, but in their forms of vegetation. In both cases, the gradient of light determines the distribution of living things, and its intensity produces an extraordinary variety of plants and epiphytes. The diversity of forms and colors of those vegetable species is the expression of complex strategies that compete to gain a place that provides access to the sun's rays. His explorations of those dense tropical jungles gave Miranda the opportunity to traverse the marine forests of the Atlantic, without water and on a much greater scale.

His other great contribution, the classification of vegetable types in Mexico, was the product of over two decades of research. He published the most complete version just a year before his death, co-authored with his Mexican disciple, Efraím Hernández Xolocotzi. That opus offers a 
general characterization of vegetation throughout the country, as if seen from a helicopter, and it is still extraordinarily important for botanists and agronomists. This approach to the study of nature was highly-intuitive for a marine phycologist. The regular oscillations caused by the tides determine constant patterns in the vertical distribution of different species of seaweed, from the upper littoral to the infra-littoral. Suffice to observe a small, rocky, intertidal area to recognize the associations of seaweed and their succession as a function of the time they spend out of water. Miranda was a pioneer in studies of marine phytogeography in Spain, a field he first explored in an article published in 1929, and developed more broadly in his doctoral thesis. His first scientific work published in Mexico, in 1941, was written from that same perspective as the introduction to a five-part series edited under the title La vegetación de México, which examined the successions of vegetation in different regions of the country.

Without question, this unanticipated alliance between Spanish seaweed and terrestrial flora in Mexico served as a bridge that allowed Miranda to resume his research in exile. But, in addition, it determined the orientation of his work, which came to consolidate a whole new field of research -tropical flora- and established the discipline of geobotany in Mexico.

\section{A FERTILE ALLIANCE BETWEEN SARDINES AND CHARALES}

The second case is that of the Catalan marine biologist, Fernando de Buen Lozano, who arrived in Mexico in 1939 at the age of 43, carrying on his back over two decades of experience in oceanographic research conducted in various marine biology laboratories and, after 1914, at the Instituto Español de Oceanografia, founded in that year by his father, Odón de Buen. De Buen's publications span an extraordinarily ample array of topics: from the taxonomy of marine fish to studies of the population dynamics and trophic chains of species of interest to the fishing industry, especially sardines, a staple food along Spanish coastlines in that period. His research entailed long campaigns of oceanographic study aboard warships loaded with heavy dragging equipment, nets and other gear that allowed him to take samples and relate the behavior of species to physical and chemical parameters.

In Mexico, De Buen was sent to Morelia (Michoacán) to give classes in the Colegio de San Nicolás de Hidalgo and direct the operations of an experimental station created two years before on the shores of nearby Lake Pátzcuaro. That station had raised lofty expectations, for its founders were sure that it would produce the scientific knowledge required to improve the living conditions of nearby indigenous populations. But a lake's behavior differs markedly from that of an ocean. De Buen lobbied insistently for a commission to work on the coast of Michoacán, where his training in oceanography would allow him to foment the fishing industry (Dosil Mancilla, 2010: 260). But the authorities denied his requests, leaving him no other choice than to apply his knowledge of oceans to a lake environment. For four years, he explored lakes and rivers from a perspective heavily-influenced by oceanography that included studies of currents, trophic chains, and the relation between biological activity and temperature, $\mathrm{pH}$, and salinity, etc. His application of oceanographic procedures to the study of Lake Pátzcuaro practically introduced a new scientific discipline into Mexico: limnology.

The main agents that propitiated this particular shift were, on the Spanish side, sardines, and on the Mexican side, charales and whitefish (both of the genus Chirosto$m a)$, which were staples in the diet of that lake region. In other words, the studies of those two species that De Buen conducted largely followed the model of his work on sardines back in Spain. His final publication before exile had been an extensive monography on sardines (1937); his next work -which appeared three years later-presented the results of an initial study of charales and whitefish. The alliance between these species eased his transition from Spain to Mexico by laying a bridge that allowed him to carry on his research and introduce limnological studies into his adopted country; a story of alliances whose protagonists included not only sardines, charales and whitefish, but also lakes and oceans, scientists both Spanish and Mexican, politicians, dragging gear, microscopes, thermometers and many other elements.

While we have explored only two cases -those of Miranda and De Buen- this shifting of goals was a frequent phenomenon among scientists in exile. Dionisio Peláez, for example, had to abandon his area of specialization (grasshopper taxonomy), and so shifted to parasitology; the trajectory of Federico Bonet, an expert on beetles, veered towards ecology, genetics and, finally, paleontology; while Isaac Costero switched from nerve tissue to cardiovascular tissue upon entering the Instituto Nacional de Cardiología in Mexico. These were by no means minor shifts, and the success of these exiled scientists in their new disciplines was never assured. Though it is important to stress, a posteriori, the professional expertise and solid academic training of those scientists, we can never lose sight of the fact -waxing rather poeticallythat those plants and animals never left their side.

\section{CONCLUSIONS}

Scientific exile presents an extraordinarily dynamic social process in which two forces act from the first moment: one intervening violently to disperse the nodes of a network, another operating in the opposite direction -but no less vigorously- to reaffirm links and reunite actors physically and symbolically. While the first is inherent to exodus, the second was the expression of a community that persisted even when deprived of its territory. The exiles' highest-priority consisted, precisely, in securing a land they could call their own, in an imaginary -i.e., finding a country that would take them in- but, above all, symbolic sense (i.e., maintaining unity as a collective). This territory is the cartography of Republican 
exiles: a network where processes of "deterritorialization" and "reterritorialization" operated simultaneously, like two knitting needles that remade the fabric of peregrine science. These two Deleuzian concepts seem to be more appropriate for studying the dynamics of scientific exile than "banishment" and "transtierro" or, what is much the same, rupture and continuity, for they allow us to penetrate deeply into the web of exile without renouncing our intention to understand it as a 'hot' scenario; that is, without pushing movement and constant changes of meanings to the margins.

The route that led these exiled scientists to their new -imaginary or symbolic- territory, could not follow the channels that had led them into exile. Whereas the nature of exodus was violent, their "reterritorializations" were resolved by creating alliances with multiple actors. As paradoxical as it may seem, the science of exiled Spaniards led inevitably to re-encounters. The network multiplied its nodes, reaffirmed links and began to interact with other networks. To gain an idea of its complexity, it is useful to conceive it as a network of networks, a contour map subject to intense tectonic processes: faults, depressions and rifts. Faults represent the distancing between nodes caused by the diaspora; depressions act by tilting their slope to channel diverse actors towards shared interests; and rifts help us understand how even the slightest movement can profoundly alter the distance between nodes. My intention in discussing these three examples is to explore alternatives to the metaphor of the pathway -which hardly seems propitious for studying exile- as support for historical interpretation through a multidimensional symbolic representation that I call the Projective Cartography of Meanings.

But this network of networks would be incomplete if we omitted plants, animals, instruments, publications, etc., because these, together with the human element, forge a dense matrix whose components cannot be analyzed separately without running the risk of dismantling the whole. Those actors accompanied scientists in their diaspora and generated alliances that facilitated their professional legitimation and integration, while catalyzing the critical process that eventually allowed them to resume their research in the countries that welcomed them. We can represent these alliances as associations (or syntagmatic chains) made up of diverse actors, not just humans. A change in the composition or order of the actors in a chain presupposes a shift in its meaning. In other words, in a cartography or network, the meaning of one node is a function of both its topos (the place it occupies) and its relations with the other nodes. Such shifts were a constant in the science that those exiles performed (hence, it is unadvisable to refer to them as continuities) that help explain, for example, how alliances of a humanitarian or political character translated into scientific collaborations and vice versa, and how they so often produced apertures in host countries... new routes and even new scientific disciplines (geobotany and limnology).

Without doubt, exile constitutes a network of networks that tends to expand and reveals an enormous capacity to stimulate the mobilization of the world. Its impact on receiving countries proved decisive by fostering the vascularization of science.

\section{REFERENCES}

Casado, Santos (1996) «Naturalistas en el exilio. ¿Nueva España en el Nuevo Mundo?». In Los refugiados españoles y la cultura mexicana, edited by Valender, James. El Colegio de México and Residencia de Estudiantes, México: 483-499.

Dosil Mancilla, Francisco Javier (2006) «La Sociedad Mexicana de Historia Natural, un espacio de encuentro entre los naturalistas del exilio republicano y los científicos mexicanos». In Actas del IX Congreso de la Sociedad Española de Historia de la Ciencia $y$ de la Técnica, edited by Pérez-Bustamante, Juan Antonio. Universidad de Cádiz, Cádiz: 1085-1095.

Dosil Mancilla, Francisco Javier (2007) «Faustino Miranda. Avance para una biografía pendiente». In Faustino Miranda. Una vida dedicada a la botánica, edited by Dosil Mancilla, Francisco Javier. Universidad Michoacana and CSIC, México: 13-89.

Dosil Mancilla, Francisco Javier (2009) «La estela de Cajal en México». Arbor, 185 (735): 29-40.

Dosil Mancilla, Francisco Javier (2010) «La dinámica de las redes del exilio científico». In El exilio científico republicano, edited by Barona, Josep L. Universitat de València, Valencia: 249-262.

Dosil Mancilla, Francisco Javier and Cremades, Javier (1999) «Sobre un trabajo olvidado de Faustino Miranda: Enumeración de las algas del N. y NO. de España (1943-44)». Algas, 20: 7-9.

Dosil Mancilla, Francisco Javier and Ramos García, Jacqueline Alejandra (2011) «Tejer el destierro. Las redes científicas e intelectuales del exilio republicano español en México». In De la posrevolución mexicana al exilio republicano español, edited by Serra Puche, Mari Carmen, Mejía Flores, José Francisco and Sola Ayape, Carlos. Fondo de Cultura Económica, México: 283-306.

Fernández Guardiola, Augusto (1997) Las neurociencias en el exilio español en México. Fondo de Cultura Económica, México.

Guerra, Francisco (2003) La medicina en el exilio republicano. Universidad de Alcalá, Madrid.

Izquierdo, José Joaquín (1966) Desde un alto en el camino. Libros de México, México.

Martínez Vidal, Álvar and Sallent del Colombo, Emma (2010) «Entre el éxodo y la diáspora: Albert Folch Pi, Joaquín D’Harcourt y la tentativa de reconstitución de la Escuela Biológica Catalana en Francia (1939-1941)». In El exilio científico republicano, edited by Barona, Josep L. Universitat de València, Valencia: 137-155.

Miranda, Faustino (1963) «Así vi yo a Standley». In Homage to Standley, edited by Williams, Louis O. Chicago Natural History Museum, Chicago: 23-26.

Ortega y Gasset, José (1930) La rebelión política de las masas. Revista de Occidente, Madrid.

Prigogine, Ilya and Stengers, Isabelle (2004) La nueva alianza. Metamorfosis de la ciencia. Alianza, Madrid. 